\title{
The Great War and Its Significance for Law, Legal Thinking and Jurisprudence
}

Willem H. van Boom*

\section{Introduction}

This year we commemorate the centenary of the outbreak of the Great War, the First World War. The remembrance events, museum exhibitions, TV programs and numerous publications rightly draw attention to the Great War. Obviously, in the past century much scholarly work has been dedicated to the Great War, its causes and consequences and its lasting impact on individuals, societies, economies and cultures. However, considerably less material is available on what effects - if any - the Great War had on the development of law, legal thinking and jurisprudence. This issue of Erasmus Law Reviem is dedicated to that particular significance of the Great War, be it confirmed, alleged or disputed significance. It was the great Rudolph von Jhering who posited: '[...] war can exert a wholesome influence on legal development is less a paradox than it appears. A well-timed war can do more to encourage development in few years than centuries of peaceful existence'. ${ }^{1}$ Did the Great War indeed have this 'wholesome influence' on legal developments or was the War a mere ripple or perhaps a prelude to bigger and worse things to come? Arguably, the War had been a long time coming. The conditions set by nineteenth-century imperialist expansionism and the concomitant arms race, together with the sparks in the powder keg caused by the least democratic nations in Europe (the German, AustrianHungarian and Russian monarchies) started the inferno of an unparalleled War that was to rage over Europe for

* Prof dr. Willem van Boom is a professor of law. As of August 2014, he holds tenure at Leiden Law School.

1. „Daß der Krieg auf die Entwicklung des Rechts und Staats den heilsamsten Einfluß ausüben kann, ist weniger paradox, als es klingt. Ein Krieg zur rechten Zeit kann diese Entwicklung in wenig Jahren mehr fördern, als Jahrhunderte friedlicher Existenz". See R. von Jhering, Geist des römischen Rechts auf den verschiedenen Stufen seiner Entwicklung. Erster Theil (Verlag von Breitkopf und Härtel, Leipzig 1852), at 239. four long bloody years. ${ }^{2}$ The War was of an unparalleled scale. It was global in the sense that it spread to colonies and dominions in Asia and Africa. It was total in the sense that combat was waged on land, by sea and in the air. ${ }^{3}$ By the time the Armistice was agreed on 11 November 1918, some eight million people had lost their lives. ${ }^{4}$ Although the emphasis in the Western European narrative usually lies on the sickening waste of human life on Belgian and French soil, not many know that it was actually the Serbians who suffered the most casualties relative to the size of their population. ${ }^{5}$

The day before the Armistice, in the early morning hours of November 10, the erratic and out-of-touch Kaiser Wilhelm II and his entourage had stopped their nine motor vehicles en route from Spa in the insignificant Dutch border village Eijsden to ask permission to obtain asylum in the Netherlands. ${ }^{6}$ The Dutch government grasped the opportunity to operationalise their coveted doctrine of neutrality and granted Wilhelm asylum. Attempts by French prime minister, Clemenceau, and British prime-minister, Lloyd George, to bully the Dutch into handing over their political refugee led to nothing; the Dutch were not prepared to give in. ${ }^{7}$ Wilhelm got to spend the rest of his life in exile in a tiny Dutch castle, which was stuffed with the contents of the many railway carriages that followed him to the Netherlands. ${ }^{8}$ Ironically, when Wilhelm died in 1941 the world was at war again, only this time the Netherlands was firmly occupied by the Germans.

2. On the background variables imperialism, expansionism and arms race that set the scene for the Great War, see, e.g. G. Hardach, The First World War 1914-1918 (Allan Lane, London 1977); P. Kennedy, The Rise and Fall of the Great Powers - Economic Change and Military Conflict from 1500 to 2000 (Random House, New York 1987), at 194 ff.; J. Sperber, Europe 1850-1914 (Pearson Longman, London 2009), at 302; R. Findlay and K.H. O'Rourke, Power and Plenty - Trade, War, and the World Economy in the Second Millennium (Princeton U.P., Princeton 2007), at $387 \mathrm{ff}$.

3. Cf. G. Hirschfeld and G. Krumeich, Deutschland im Ersten Weltkrieg (S. Fischer Verlag, Frankfurt a.M. 2013), at 95 f.

4. Precise numbers of casualties which can be directly attributed to the Great War are unavailable and are skewed by related causes of death such as food shortages, disease and deprivation (combined with flue epidemics). Numbers seem to vary from 7 to 15 million. Cf. E. Damsgaard Hansen, European Economic History - From Mercantilism to Maastricht and Beyond (CBS Press, Copenhagen 2012), at $202 \mathrm{ff}$.

5. Hirschfeld and Krumeich, above n. 3, at 94.

6. C. Smit, Nederland in de Eerste Wereldoorlog - Derde deel 1917-1919 (Wolters-Noordhoff, Groningen 1973), at $8 \mathrm{ff}$.

7. M. Carter, George, Nicholas and Wilhelm - Three Royal Cousins and the Road to World War I (Knopf, New York 2010), at 416.

8. The castle, ornately decorated with imperial paraphernalia, is open to the public. See <www.huisdoorn.nl>. 
The Great War left Europe destroyed and uprooted by combat, migration and border corrections. Moreover, it left the belligerent countries - both victors and vanquished - cash-strapped and in debt for decades. ${ }^{9}$ The 440 articles of the 1919 Versailles Treaty in all their detail compelled the Central Powers to accept sole responsibility for starting the Great War, ${ }^{10}$ to endure border corrections, to disarm and to make debilitating large payments to the victors. ${ }^{11}$ Thus, the peace terms brought about a state of economic and political instabili$\mathrm{ty}^{12}$ in Europe which, in hindsight, may well be considered to be the root cause of the Second World War. ${ }^{13}$ Arguably, one enduring political lesson that the Great War may hold is that conquest without a realistic perspective of rehabilitation of the vanquished not only hampers reconciliation of the peoples concerned but may also impede economic growth of all economies concerned. As early as the 1920s, Konrad Adenauer, who was later to become the founding father of the West German Republic, argued that an organic intertwining the French, Belgian and German economies would ensure lasting and sustainable peace in Europe. The future lay in a United States of Europe. ${ }^{14}$

The Great War was different from previous wars - through its scale and intensity it reached and affected just about every corner of European society. The outbreak of the War caused the Western international trade and payment systems to come to a grinding halt. In the first weeks currencies faltered, coinage was hoarded, stocks plummeted and stock trade was quickly suspended. The legislative response to all this was swift but makeshift. Piecemeal moratoria were hastily introduced to create breathing space for debtors who, due to the collapse of international and national trade and banking, found themselves in unexpected liquidity problems and

9. D.H. Aldcroft, From Versailles to Wall Street 1919-1929 (Allen Lane, London 1977); H. Strachan, Financing the First World War (Oxford U.P., Oxford 2004) ; H-C. Kraus, Versailles und die Folgen - Außenpolitik zwischen Revisionismus und Verständigung 1919-1933 (be.bra Verlag, Berlin 2013).

10. Art. 231 Versailles Treaty provided: 'The Allied and Associated Governments affirm and Germany accepts the responsibility of Germany and her allies for causing all the loss and damage to which the Allied and Associated Governments and their nationals have been subjected as a consequence of the war imposed upon them by the aggression of Germany and her allies.'

11. Cf. Kraus, above n. 9, at $27 \mathrm{ff}$.

12. On these destabilising economic consequences, e.g., S. Broadberry and K.H.O'Rourke (eds.), The Cambridge Economic History of Modern Europe - Volume 2: 1870 to the Present (Cambridge U.P., Cambridge 2010), at 134.

13. The causal chain between the harsh treaty terms and subsequent events such as the 1920s hyperinflation and the rise of the German National Socialist Party is contested among historians. See, e.g. Kraus, above $\mathrm{n}$. 9, at 149 f.; K. Wiegrefe, 'Der Unfriede von Versailles', in S. Burgdorff and K. Wiegrefe (eds.), Der Erste Weltkrieg - Die Ur-Katastrophe des 20. Jahrhunderts (Deutscher Taschenbuch Verlag, München 2008), at 235 ff; Hirschfeld and Krumeich, above n. 3, at 265 ff.; Hardach, above n. 2, at 294; N. Ferguson, The Pity of War 1914-1918 (Penguin, London 1999), at $397 \mathrm{ff}$.

14. H.P. Schwarz, Adenauer. Der Aufstieg: 1876-1952, 3rd edn. (Stuttgart, DVA 1991), at 513-15. were unable to pay their debts as a result. ${ }^{15}$ To counter the unbalancing effects of coinage hoarding and bank runs, either formal restrictions on cash withdrawals or informal dissuasion policies were applied. ${ }^{16}$ Later, the belligerent nations experienced inflation and dramatic exchange rate fluctuations, necessitating some countries to suspend the gold standard.

Apart from these emergency responses, the Great War also marked the beginning of the end of the long nineteenth century for European economies and societies. The Victorian laissez-faire approach to society and markets, in which freedom of trade and contract was deemed normatively superior to protection of labourers, tenants, the poor and weaker parties generally, was already eroding fast in the late nineteenth century and early twentieth century. Universal suffrage was in the air, the labour rights movement was firmly established and the plight of the lower classes had more political relevance than a hundred years earlier. The Great War did not cause these developments, but it did much to accelerate them.

The experience of a drawn-out war of this scale and intensity was new. It necessitated rethinking of the economic framework of state and society both in terms of the regulatory architecture of markets - ranging from foodstuffs to financial products, from fuel to transport services - and the budgetary choices and leeway of nation states. The Great War prompted the introduction of emergency interventionist legislation for most parts of socio-economic life. Thus, it introduced restrictions on freedom of contract in the areas of labour, rent and housing, food production and transport. Typical war provisions such as trading restrictions were introduced and increasingly tightened. Moreover, market interventions ranging from price capping to property requisitioning, forced purchase and compulsory (re)distribution of scarce resources were introduced on an unparalleled scale. All this marked a permanent change of the role of the state; when the guns were finally silenced, the state had become the regulator of economic life and the distributor of wealth. Its role would never change back to that which it had assumed during the long nineteenth century.

The Great War had a huge impact on state finances. Not merely the cost of combat itself but also the enduring expense of war pensions caused a lasting rise in government expenditure of the combatant nations. Moreover, the Great War necessitated governments to redesign their legislative frameworks for securing income streams. Initially, financing the war effort was a far bigger problem for those countries such as France, which did not have direct taxation instruments easily adjustable to generate revenues to alleviate sovereign debt, and Germany, which did have an imperial army but lacked

15. Cf. R. Roberts, Saving the City - The Great Financial Crisis of 1914 (Oxford U.P., Oxford 2013); M. Lobban, 'Introduction: The Great War and Private Law', 2 Comparative Legal History (2014) forthcoming).

16. Some countries introduced 'substitute coinage' in paper tender. See P. Moeyes, Buiten Schot - Nederland tijdens de Eerste Wereldoorlog (Arbeiderspers, Amsterdam 2001), at $164 \mathrm{ff}$. 
the power of direct federal (income) taxation. ${ }^{17}$ Therefore, in comparison to the UK, France and Germany had to rely more on other instruments of financing such as government bonds and money creation than on taxation. ${ }^{18}$ Traders who profiteered from war conditions were levied a war profits tax.

Naturally, the Great War also signalled a next stage in the development of international law and its theoretical underpinnings. As a direct outcome of the War, the Versailles Treaty created the League of Nations for the promotion of global peace and stability.

\section{The Contributions}

From the previous, it is clear that the Great War and all it entailed had a lasting impact on societies, markets, the political landscape in European countries and on the trajectory of international law. As a consequence, the legal doctrines and conditions somehow changed as well. In the contributions to this issue of Erasmus Lam Reviem, four different viewpoints of this change are presented: colonial constitutional law and governance, contract law, international relations and public international law, and finally international criminal law. Obviously, these four themes do not cover the entirety of the breadth of subjects that could be addressed in this regard. They do, however, exemplify the influence of the Great War on law, legal thinking and jurisprudence. The first theme concerns colonial constitutional law and governance. In his contribution titled 'The First World War and the Constitutional Law for the Netherlands Indies', Nick Efthymiou asks what the contribution of the Great War was to two major events in the Netherlands Indies constitutional governance structure. Obviously, the War made communication, travel and trade between the Netherlands and the Netherlands Indies difficult. But did it also cause a shift in constitutional law and governance? It may well have. In 1918, a representative body 'People's Council' was introduced and accelerated constitutional reform was promised to the colony. The question is whether the Great War caused or accelerated these developments. In his contribution,

17. A. Gaaff, Financiering van de Eerste Wereldoorlog - Vier jaar vechten op krediet (Uitgeverij Aspekt, Soesterberg 2014), at $69 \mathrm{ff}$. In the Netherlands, following a lengthy process of parliamentary proceedings starting in 1906, a new system of income taxation was introduced in 1914 (Wet van 19 December 1914, Staatsblad 1914, no. 563). See J.H.R. Sinninghe Damsté, De Wet op de Inkomstenbelasting en de Wet op de Verdedigingsbelasting II (2nd edn. W.E.J. Tjeenk Willink, Zwolle 1923), at 31 ff.; J. Visser and M. Visser, 'Profijt en protest - Verscherping der sociale tegenstellingen in Nederland gedurende de Eerste Wereldoorlog', in H. Binneveld (ed.), Leven naast de catastrofe Nederland tiidens de Eerste Wereldoorlog (Verloren, Hilversum 2001), at $93 \mathrm{ff}$. The new Income Tax Act (ITA) 1914 charged tax on income from immovable and movable property, business and employment and annuities and pensions. See H. Vording and O. Ydema, 'The Rise and Fall of Progressive Income Taxation in the Netherlands (1795-2001)', British Tax Review 255, at 271 (2007)

18. Gaaff, above n. 17, at $69 \mathrm{ff}$. This was especially the case in the first half of the War - legislative intervention in France and Germany soon addressed these deficiencies.
Efthymiou dissects the various mechanisms and concludes that one of the two developments, the promise of reform, can indeed be traced back to the Great War.

The second theme concerns contract law; it explores how courts in Europe grappled with the question how contract law doctrines should respond to the economic chaos and upheaval caused by the Great War. Janwillem Oosterhuis investigates 'Unexpected Circumstances Arising from World War I and Its Aftermath: “Open” versus “Closed” Legal Systems'. His comparative analysis of French, German, English and Dutch contract law shows that courts were consistently reticent to allow the War to serve as an excuse for non-performance of contractual obligations. Thus, the judicial approach to unforeseen circumstances was more 'closed' than 'open'. The devastating effects of the hyperinflation of the German currency in the 1920s, however, opened the door to a more debtor-friendly approach. The author thus concludes that it was not the Great War itself but the economic turmoil afterwards that caused this paradigmatic shift.

The third theme centres around the development of public international law thinking in the United States before and after the Great War. Ignacio de la Rasilla del Moral analyses 'The Ambivalent Shadow of the Pre-Wilsonian Rise of International Law'. By focussing on the pedigree of the American international lawyers who founded the American Society of International Law at the beginning of the twentieth century, the author is able to present a fuller picture of the ethical and legal stance of these founders. Further, by showing the full chronology from as early as the 1898 Spanish American War to well beyond the Great War, the author identifies some of the factors that were conducive in the development of the American approach to international. In doing so, the analysis sheds light on such issues as the position of the United States vis-à-vis the League of Nations and the development of international law theory after the Great War.

The fourth theme is concerned with what we would now call international criminal law. Co-authors Paul Mevis and Jan Reijntjes deal with the intriguing 'what if' question raised by Article 227 of the Versailles Treaty. The Allied and Associated Powers held Wilhelm II of Hohenzollern to account for waging war. The Treaty was the legal basis for the institution of a Tribunal where he would betried for violating treaties and offences against international morality. The trial never happened, but what if it had happened? Would the Emperor have been convicted, and would it be justice? Would it have paved the way for the Nuremberg trials? In conclusion, we feel the pictures painted in these four contributions add to the literature on the ramifications of the Great War for law, legal thinking and jurisprudence. We thank the contributors and the reviewers for their willingness to compile a fitting commemoration of one of the greatest atrocities suffered by mankind. We hope the reader considers this issue of Erasmus Lam Reviem a fitting tribute. 